\title{
Atomic Structure of Pd-, Pt-, and PdPt-Based Catalysts of Total Oxidation of Methane: In Situ EXAFS Study
}

\author{
Andrey A. Saraev ${ }^{1,2, *} \mathbb{C}$, Svetlana A. Yashnik ${ }^{1}$, Evgeny Yu. Gerasimov ${ }^{1}{ }^{\oplus}$, Anna M. Kremneva ${ }^{1}{ }^{(D}$, \\ Zakhar S. Vinokurov ${ }^{1,2}$ and Vasily V. Kaichev ${ }^{1}$ \\ 1 Department of Investigation of Catalysts, Boreskov Institute of Catalysis, Lavrentev Ave., 5, \\ 630090 Novosibirsk, Russia; yashnik@catalysis.ru (S.A.Y.); gerasimov@catalysis.ru (E.Y.G.); \\ kremneva@catalysis.ru (A.M.K.); vinzux@mail.ru (Z.S.V.); vvk@catalysis.ru (V.V.K.) \\ 2 Synchrotron Radiation Facility SKIF, Boreskov Institute of Catalysis, Nikol'skiy Ave., 1, \\ 630559 Kol'tsovo, Russia \\ * Correspondence: asaraev@catalysis.ru
}

\section{check for} updates

Citation: Saraev, A.A.; Yashnik, S.A.; Gerasimov, E.Y.; Kremneva, A.M.; Vinokurov, Z.S.; Kaichev, V.V. Atomic Structure of Pd-, Pt-, and PdPt-Based Catalysts of Total Oxidation of Methane: In Situ EXAFS Study. Catalysts 2021, 11, 1446. https:// doi.org/10.3390/catal11121446

Academic Editors: Olga A.

Kirichenko, Elena A. Redina and Anastasiya A. Shesterkina

Received: 10 November 2021 Accepted: 26 November 2021 Published: 27 November 2021

Publisher's Note: MDPI stays neutral with regard to jurisdictional claims in published maps and institutional affiliations.

Copyright: (c) 2021 by the authors. Licensee MDPI, Basel, Switzerland. This article is an open access article distributed under the terms and conditions of the Creative Commons Attribution (CC BY) license (https:/ / creativecommons.org/licenses/by/ $4.0 /)$.

\begin{abstract}
In this study, $3 \% \mathrm{Pd} / \mathrm{Al}_{2} \mathrm{O}_{3}, 3 \% \mathrm{Pt} / \mathrm{Al}_{2} \mathrm{O}_{3}$ and bimetallic $(1 \% \mathrm{Pd}+2 \% \mathrm{Pt}) / \mathrm{Al}_{2} \mathrm{O}_{3}$ catalysts were examined in the total oxidation of methane in a temperature range of $150-400{ }^{\circ} \mathrm{C}$. The evolution of the active component under the reaction conditions was studied by transmission electron microscopy and in situ extended X-ray absorption fine structure (EXAFS) spectroscopy. It was found that the platinum and bimetallic palladium-platinum catalysts are more stable against sintering than the palladium catalysts. For all the catalysts, the active component forms a "core-shell" structure in which the metallic core is covered by an oxide shell. The "core-shell" structure for the platinum and bimetallic palladium-platinum catalysts is stable in the temperature range of $150-400{ }^{\circ} \mathrm{C}$. However, in the case of the palladium catalysts the metallic core undergoes the reversible oxidation at temperatures above $300{ }^{\circ} \mathrm{C}$ and reduced to the metallic state with the decrease in the reaction temperature. The scheme of the active component evolution during the oxidation of methane is proposed and discussed.
\end{abstract}

Keywords: bimetallic catalysts; total methane oxidation; core-shell structure; high-angle annular darkfield imaging scanning transmission electron microscopy (HAADF STEM); in situ EXAFS spectroscopy

\section{Introduction}

Over the last decade, in the field of heterogeneous catalysis, specific attention has been paid to the synthesis of the bi- and trimetallic catalysts exhibiting unique properties in various catalytic reactions [1-7]. The research interest in such systems relies on the fact that their electronic and atomic structure, morphology, etc. could be considerably different from those of a monometallic system, resulting in enhanced catalytic activity, stability, and selectivity [8-10]. The starting point in the development of bi- and trimetallic systems can be considered the application of the three-way catalysts (TWC) for the neutralization of the vehicle exhaust. The TWC is used to reduce $\mathrm{CO}, \mathrm{CH}_{\mathrm{x}}$, and $\mathrm{NO}_{\mathrm{x}}$ emission and the active component is based on $\mathrm{Pt}, \mathrm{Pd}$, and $\mathrm{Rh}$ supported on inert oxides [11,12]. Platinum provides a high rate of $\mathrm{CO}$ oxidation, palladium is known to be one of the most active catalysts for the total oxidation of hydrocarbons, and rhodium exhibits unique catalytic properties in the reduction of nitrogen oxides. Nowadays, natural gas vehicles have become popular and the problem of the neutralization of unburned methane has arisen [13-15].

The combustion of methane is also an important industrial process due to its environmental impacts and has attracted research attention for decades. Despite being a hot topic, there is no agreement about the nature of active species of the Pd-based catalysts in the total oxidation of methane. Some groups believe that PdO is an active species [14,16-18], while others attribute the high activity of the catalyst to palladium in the metallic state $[19,20]$, and there is the idea that the presence both $\mathrm{PdO}$ and metallic $\mathrm{Pd}$ is necessary to ensure high 
activity $[21,22]$. Moreover, there are conflicting opinions concerning the particle size effect in the total oxidation of methane. The absence of any catalytic effect due to the particle size was observed by Zhu et al. [23]. Chen et al. found a decrease in activity with an increase in the Pd particle size [18]. The increase in catalytic activity with particle size was reported by Stakheev et al. [24] and Murata et al. [25].

An alternative way to increase the activity and stability of the supported metal catalysts is the use of bimetallic nanoparticles. In this case, the atomic structure of nanoparticles can significantly affect their catalytic properties. Indeed, a synergistic effect is observed for the Au-Pd catalysts active in the selective dehydrogenation of benzyl alcohol to benzoic aldehyde [26]. The similar synergistic effect is observed for the Pd-Ni catalysts in the oxidation of $\mathrm{CO}$ [27] and for Pt-Pd $/ \mathrm{Al}_{2} \mathrm{O}_{3}-\mathrm{MnO}_{\mathrm{x}}$ catalysts in the oxidation of $\mathrm{CO}, \mathrm{CH}_{\mathrm{x}}$ [28]. It has been shown that the formation of a Pd-Pt alloy could significantly increase the stability of the catalysts in the total oxidation of methane [29-33].

It should be stressed that the study of bi- and trimetallic catalysts is a complex challenge, since it is necessary to determine not only the chemical state of the metals, but also the atomic structure of the nanoparticles formed. In the case of bimetallic catalysts, the active component could exist in the form of separated monometallic nanoparticles, be an alloy of metals, or have a so-called "core-shell" structure. Moreover, the structure of nanoparticles can change under the influence of reaction conditions [7,31,34-37]. The understanding of the atomic structure of the active component and its evolution under the reaction conditions is necessary to develop highly active and stable catalysts.

In the present study, the oxidation of methane was performed over alumina supported monometallic Pd-, Pt-, and bimetallic PdPt-based catalysts. High-angle annular dark-field scanning transmission electron microscopy (HAADF STEM) was used to determine the particle size distribution of synthesized catalysts and energy dispersive $\mathrm{X}$-ray analysis was used to prove the formation of alloyed PdPt nanoparticles in the case of the bimetallic PdPt-based catalyst. In situ EXAFS spectroscopy was used to obtain the quantitative information about changing the oxidation state of palladium and platinum under the reaction conditions. Moreover, the combination of TEM and in situ EXAFS spectroscopy results reveals the atomic structure of the active component and its evolution under the reaction conditions.

\section{Results and Discussion}

\subsection{Catalyst's Testing}

The oxidation of methane was studied over $\mathrm{Pd} / \mathrm{Al}_{2} \mathrm{O}_{3}, \mathrm{Pt} / \mathrm{Al}_{2} \mathrm{O}_{3}$ and bimetallic $\mathrm{PdPt} / \mathrm{Al}_{2} \mathrm{O}_{3}$ catalysts in the temperature range of $150-400{ }^{\circ} \mathrm{C}$. Only $\mathrm{CO}_{2}$ and water were detected as products of the oxidation of methane for all the catalysts. To compare the catalytic activity of the catalysts under study, the temperature dependences of the methane conversion were measured. Then the light-off temperature (the temperature of reaching $50 \%$ of the methane conversion, $\mathrm{T}_{50}$ ) was determined for each catalyst. The results are presented in Figure 1. One can see that the monometallic Pd catalyst demonstrates the highest catalytic activity, and the light-off temperature is approximately $270{ }^{\circ} \mathrm{C}$. The monometallic Pt catalyst has the lower catalytic activity and $\mathrm{T}_{50}$ achieves $320^{\circ} \mathrm{C}$. As was expected, the bimetallic $\mathrm{PdPt} / \mathrm{Al}_{2} \mathrm{O}_{3}$ catalyst has intermediate catalytic activity and $\mathrm{T}_{50}$ equals to $295^{\circ} \mathrm{C}$. The differences in the catalytic activity of monometallic catalysts could be obviously explained by the higher activity of palladium than platinum in the total oxidation of methane $[14,16,24,29]$. We believe that the activity of supported catalyst correlates with the structure of the active component, as it was mentioned above that the bimetallic catalysts could have different structures of active species. It could be separate palladium and platinum nanoparticles, alloyed nanoparticles, core-shell nanoparticles, etc. For each type of structure of active species, the catalytic behavior could be different, and some synergetic effect could be expected. The correct explanation of the catalytic activity should be based on the overall information about the atomic structure of the active component. 


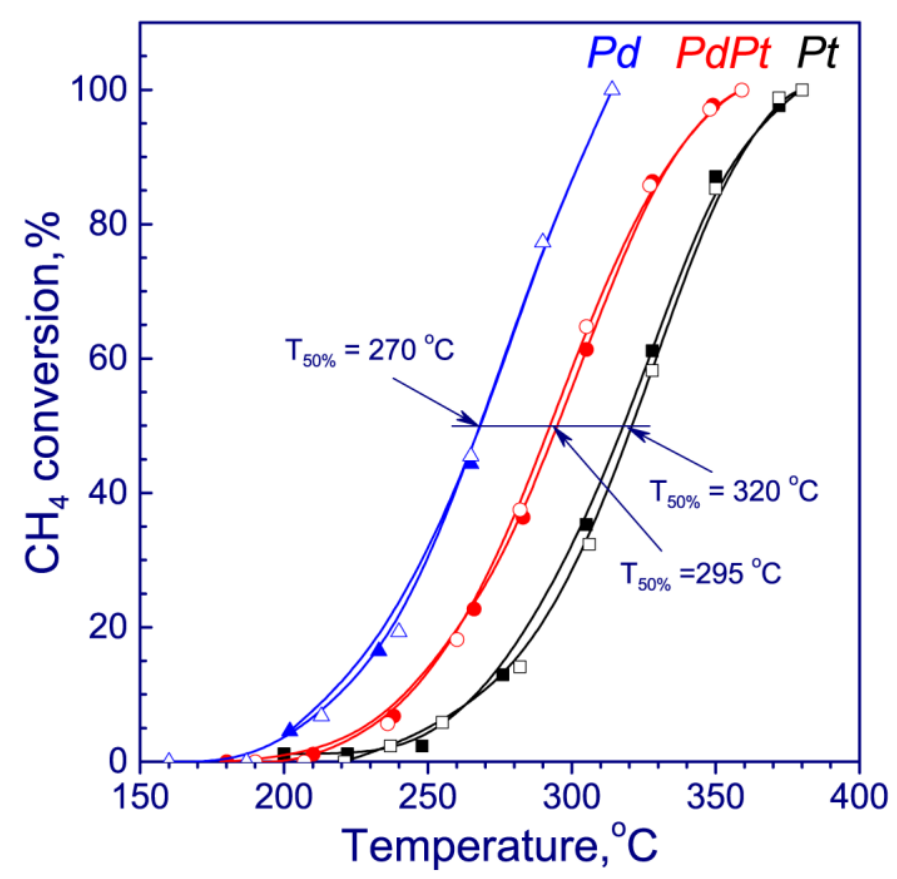

Figure 1. Methane conversion during the oxidation of methane over $\mathrm{Pd} / \mathrm{Al}_{2} \mathrm{O}_{3}, \mathrm{Pt} / \mathrm{Al}_{2} \mathrm{O}_{3}$ and bimetallic PdPt $/ \mathrm{Al}_{2} \mathrm{O}_{3}$ catalysts. Filled symbols correspond to increasing the temperature, open symbols correspond to decreasing the temperature.

\subsection{Catalyst Characterization}

\subsubsection{High-Angle Annular Dark-Field STEM Study}

HAADF STEM micrographs of the fresh and spent $\mathrm{Pd} / \mathrm{Al}_{2} \mathrm{O}_{3}, \mathrm{Pt} / \mathrm{Al}_{2} \mathrm{O}_{3}$ and bimetallic $\mathrm{PdPt} / \mathrm{Al}_{2} \mathrm{O}_{3}$ catalysts are presented in Figure 2 . The spent catalysts are the catalysts used in the oxidation of methane at the $400{ }^{\circ} \mathrm{C}$ for $3 \mathrm{~h}$. All catalysts have a uniform particle distribution over the support (light areas correspond to metal particles with high atomic number). The fresh catalysts (Figure $2 \mathrm{a}-\mathrm{c}$ ) contain nearly spherical nanoparticles with a symmetrical size distribution, the mean particle size for $\mathrm{Pd} / \mathrm{Al}_{2} \mathrm{O}_{3}$ is $2.7 \mathrm{~nm}$, whereas for both $\mathrm{Pt} / \mathrm{Al}_{2} \mathrm{O}_{3}$ and bimetallic $\mathrm{PdPt} / \mathrm{Al}_{2} \mathrm{O}_{3}$ the mean particle size is lower and about 1.1 and $1.3 \mathrm{~nm}$, respectively. Moreover, the range of size distribution for $\mathrm{Pd} / \mathrm{Al}_{2} \mathrm{O}_{3}$ is much higher than for $\mathrm{Pt} / \mathrm{Al}_{2} \mathrm{O}_{3}$ and $\mathrm{PdPt} / \mathrm{Al}_{2} \mathrm{O}_{3}$ and equals $0.7,0.3$, and $0.4 \mathrm{~nm}$, respectively. Both facts indicate that platinum leads to the formation of small nanoparticles with narrow size distribution. Figure $2 \mathrm{~d}-\mathrm{f}$ present the micrographs of the spent $\mathrm{Pd} / \mathrm{Al}_{2} \mathrm{O}_{3}, \mathrm{Pt} / \mathrm{Al}_{2} \mathrm{O}_{3}$ and bimetallic $\mathrm{PdPt} / \mathrm{Al}_{2} \mathrm{O}_{3}$ catalysts. One can find that the mean particle size of $\mathrm{Pd} / \mathrm{Al}_{2} \mathrm{O}_{3}$ increases to $3.1 \mathrm{~nm}$ whereas the one of $\mathrm{Pt} / \mathrm{Al}_{2} \mathrm{O}_{3}$ does not change. For the bimetallic $\mathrm{PdPt} / \mathrm{Al}_{2} \mathrm{O}_{3}$, a slight increase in the particle size to $1.5 \mathrm{~nm}$ is found. In fact, this means that there is sintering palladium nanoparticles under the reaction conditions (one can see the Pd particles with size of 5-7 nm). At the same time, the Pt and PdPt nanoparticles do not demonstrate significant sintering under the reaction conditions.

To prove that the synthesized bimetallic PdPt $/ \mathrm{Al}_{2} \mathrm{O}_{3}$ catalyst does not contain separated monometallic palladium and platinum nanoparticles, EDX analysis was performed. The EDX mapping of the distribution of palladium and platinum atoms is presented in Figure 3. The EDX analysis indicates that palladium and platinum are locally concentrated throughout the support and the areas of local concentration are similar for palladium and platinum. This means that the synthesis modes allow us to prepare the alloyed PdPt nanoparticles supported on $\mathrm{Al}_{2} \mathrm{O}_{3}$. The EDX analysis of the catalyst after the reaction reveals that the reaction conditions do not change the bimetallic composition of $\mathrm{PdPt}$ nanoparticles. The EDX mapping of the distribution of palladium and platinum atoms of the catalyst after reaction is presented in Supplementary Figure S1. 


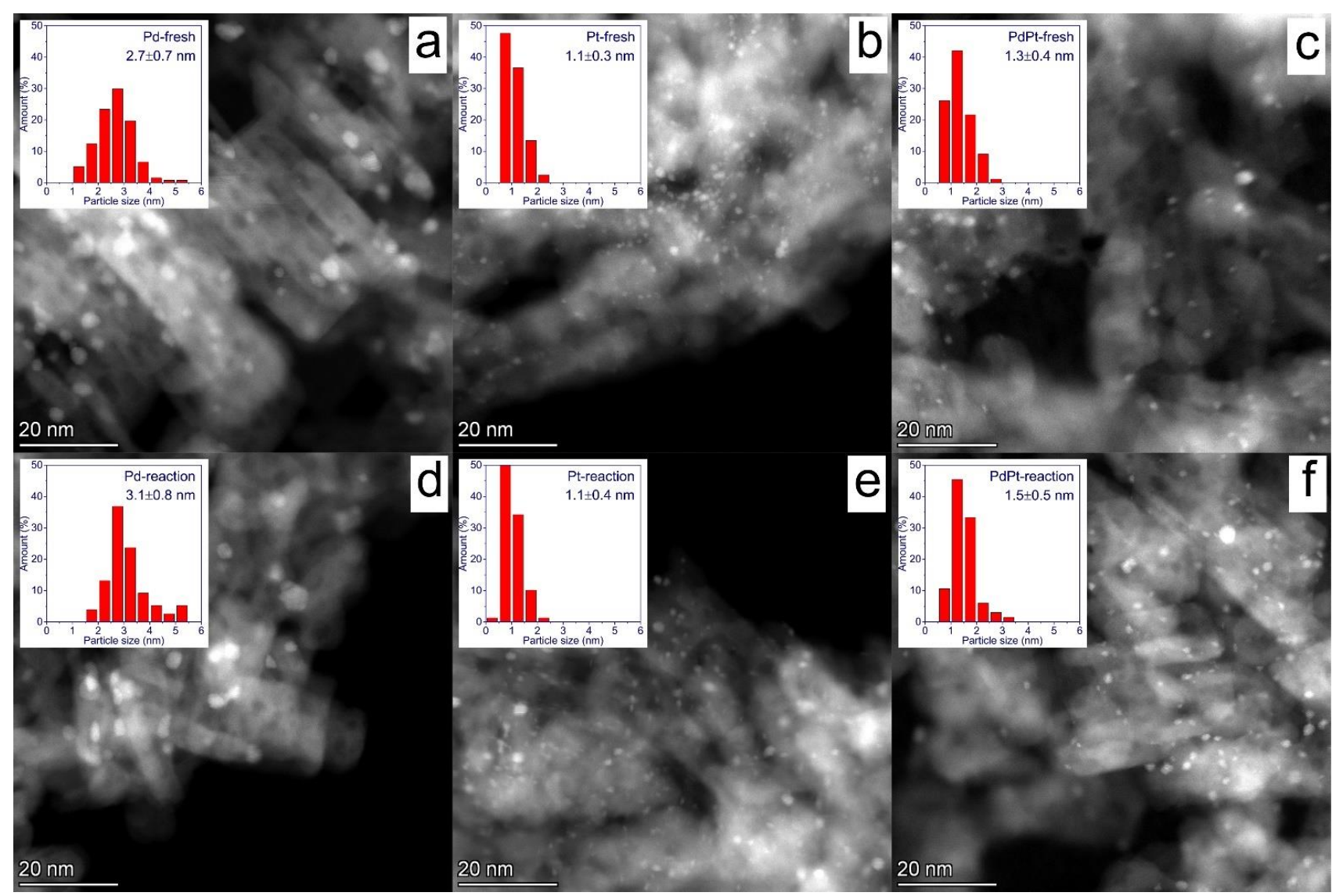

Figure 2. HAADF STEM micrographs of the $\mathrm{Pd} / \mathrm{Al}_{2} \mathrm{O}_{3}(\mathbf{a}, \mathbf{d}), \mathrm{Pt} / \mathrm{Al}_{2} \mathrm{O}_{3}(\mathbf{b}, \mathbf{e})$ and bimetallic $\mathrm{PdPt} / \mathrm{Al}_{2} \mathrm{O}_{3}(\mathbf{c}, \mathbf{f})$ catalysts before $(\mathbf{a}-\mathbf{c})$ and after using in the oxidation of methane $(\mathbf{d}-\mathbf{f})$. For each samples the particle size distribution is presented.

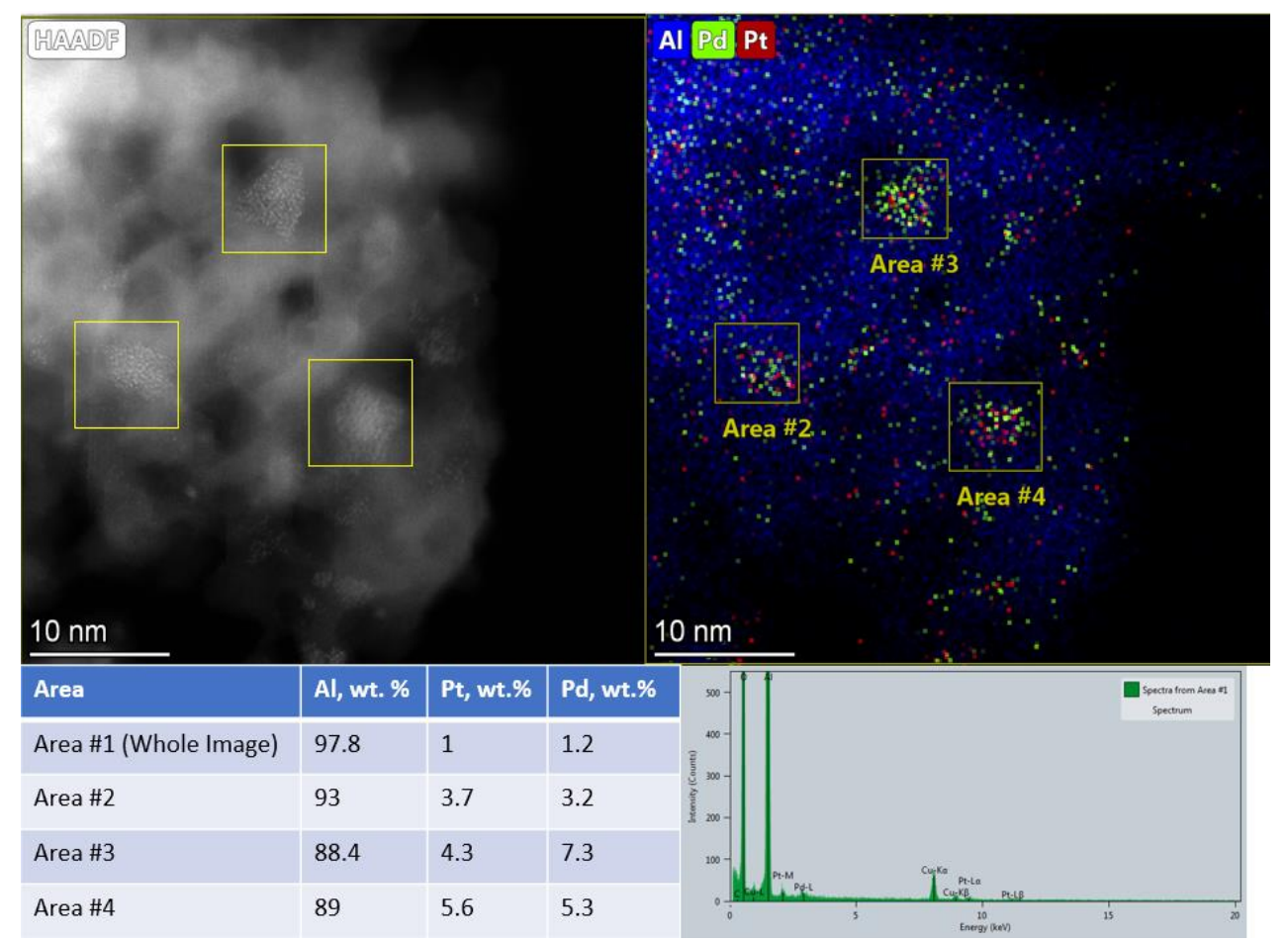

Figure 3. EDX mapping (in HAADF STEM mode) of the fresh bimetallic $\mathrm{PdPt} / \mathrm{Al}_{2} \mathrm{O}_{3}$ catalyst. 


\subsubsection{In Situ Extended X-ray Absorption Fine Structure (EXAFS) Study}

The atomic structure of the $\mathrm{Pd} / \mathrm{Al}_{2} \mathrm{O}_{3}, \mathrm{Pt} / \mathrm{Al}_{2} \mathrm{O}_{3}$, and bimetallic $\mathrm{PdPt} / \mathrm{Al}_{2} \mathrm{O}_{3}$ catalysts was studied by $\mathrm{X}$-ray absorption spectroscopy. The XAS spectra of the $\mathrm{Pd} K$-edge and $\mathrm{Pt}$ $L_{3}$-edge were measured in situ during stepwise heating from room temperature to 200, 300, and $400{ }^{\circ} \mathrm{C}$ under flow of the reaction mixture and after cooling again to room temperature. The volume (weight) of the catalysts and the flow of reactants were chosen to reach the gas hourly space velocity (GHSV) of $2000 \mathrm{~h}^{-1}$ that was used for the catalytic testing.

EXAFS Fourier transforms for the $\mathrm{Pd} K$ - and $\mathrm{Pt} L_{3}$-edges of the $\mathrm{Pd} / \mathrm{Al}_{2} \mathrm{O}_{3}, \mathrm{Pt} / \mathrm{Al}_{2} \mathrm{O}_{3}$ and bimetallic PdPt $/ \mathrm{Al}_{2} \mathrm{O}_{3}$ catalysts are presented in Figure 4. To fit the EXAFS data of the monometallic $\mathrm{Pd} / \mathrm{Al}_{2} \mathrm{O}_{3}$ and $\mathrm{Pt} / \mathrm{Al}_{2} \mathrm{O}_{3}$ catalysts, we have used two models of a nanoparticle structure: (1) the homogenous mix of metal and oxide palladium (platinum) phases and (2) the core-shell structure when the metallic core is covered by an oxide shell. For both models, the fits of all spectra were done and the best fits were obtained for the model based on the core-shell structure of nanoparticles. To reduce the quantities of variables during fitting, some of the assumptions were made for the model construction:

1. The coordination number $(\mathrm{CN})$ of the 1st coordination sphere for the palladium oxide shell was fixed and equals to 4 (the same that one for bulk PdO).

2. The coordination number of the 1st coordination sphere for the platinum oxide shell was fixed and equals to 6 (the same that one for bulk $\mathrm{PtO}_{2}$ ).

3. For all edges, additional scattering was added corresponding to the $\mathrm{Pd}-\mathrm{O}_{\mathrm{Al}}\left(\mathrm{Pt}-\mathrm{O}_{\mathrm{Al}}\right)$ scattering, where $\mathrm{O}_{\mathrm{Al}}$ is oxygen atom of the $\mathrm{Al}_{2} \mathrm{O}_{3}$ support.

4. For all edges, additional scattering was added corresponding to the $\mathrm{Pd}-\mathrm{Al}(\mathrm{Pt}-\mathrm{Al})$ scattering, where $\mathrm{Al}$ is the aluminum atom of the $\mathrm{Al}_{2} \mathrm{O}_{3}$ support.

5. The alloyed PdPt nanoparticles also has the core-shell structure and the $\mathrm{Pd}$ and $\mathrm{Pt}$ atoms could be at the same positions (this assumption does not allow us to distinguish the $\mathrm{Pd}-\mathrm{Pd}, \mathrm{Pd}-\mathrm{Pt}$ and $\mathrm{Pt}-\mathrm{Pd}$ scatterings).

The proposed model is like the one used by Nilsson et al. for fitting the Pd K-edge EXAFS spectra of $5 \mathrm{wt} \% \mathrm{Pd} / \mathrm{Al}_{2} \mathrm{O}_{3}$ catalyst for the oxidation of methane [17].

The EXAFS Pd K-edge spectrum of the fresh $\mathrm{Pd} / \mathrm{Al}_{2} \mathrm{O}_{3}$ catalyst reveals an intense peak at $\approx 1.52 \AA$ in the $\mathrm{R}-\delta$ scale, which corresponds to the $\mathrm{Pd}-\mathrm{O}$ scattering (Figure $4 \mathrm{a}$, $\mathrm{RT})$. According to the fit, this peak corresponds to the 1st coordination sphere of the palladium oxide (2.01 $\AA$ ). As was mentioned above, we have used additional scatterings that correspond to the interaction of nanoparticles and support. The region of 1.7-2.7 $\AA$ in the $\mathrm{R}-\delta$ scale corresponds to the $\mathrm{Pd}-\mathrm{O}_{\mathrm{Al}}$ and $\mathrm{Pd}-\mathrm{Al}$ scatterings of the oxide shell and the $\mathrm{Pd}-$ $\mathrm{Pd}$ scattering of the metallic core. According to the fit, the distance of $\mathrm{Pd}-\mathrm{O}_{\mathrm{Al}}$ is $2.43 \AA$ and the coordination number is 0.7 . The Pd-Pd distance for the metallic core is $2.76 \AA$ and the coordination number is 2.9. It should be noted that, according to the fit, the Pd-Al scattering is absent for the oxide shell, which could be due to the proposed model not having the reasonable sensitivity for scattering with the low coordination numbers $(<0.1-0.2)$. A wide peak in the range of 2.6-3.5 $\AA$ in the R- $\delta$ scale corresponds to two Pd-Pd scatterings of palladium oxide. According to the fit, the Pd-Pd distances are $3.04 \AA$ and $3.43 \AA$ and the coordination numbers are 2.6 and 3.3, respectively. As one can see, the coordination numbers for all scatterings (except the $\mathrm{Pd}-\mathrm{O}$ scattering for oxide shell) are lower than ones for bulk $\mathrm{PdO}$ and metallic palladium. It is well-known that the nanoparticles have lower coordination numbers for scattering than ones for bulk compounds [17,38]. The model used for fitting also allowed us to estimate the fraction of palladium atoms forming the metallic core and it is about $7 \%$. One can find more structural information obtained by fits in Supplementary Table S1. 

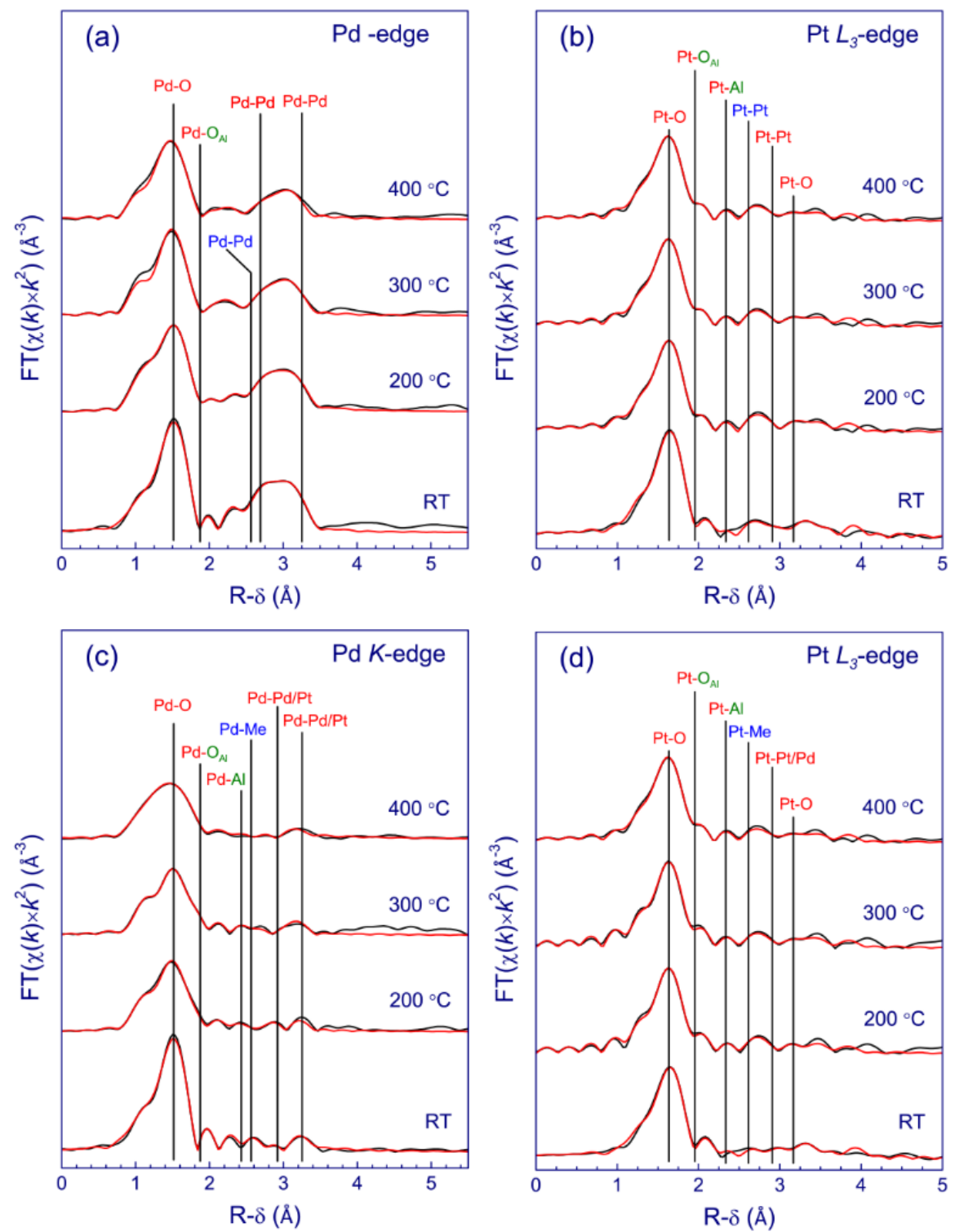

Figure 4. EXAFS Fourier transforms of the Pd K-edge of Pd (a) and PdPt (c) catalyst and Pt $L_{3}$-edge of $\mathrm{Pt}(\mathbf{b})$ and $\mathrm{PdPt}(\mathbf{d})$ catalyst EXAFS spectra obtained at different temperatures (RT, 200, 300, and $400{ }^{\circ} \mathrm{C}$ ) during the oxidation of methane. Black lines correspond to the experimental data, red lines correspond to the fit.

The increase in the temperature to $200{ }^{\circ} \mathrm{C}$ leads to a slight decrease in the coordination number that corresponds to the Pd-Pd scattering of metal core to 2.7 and the fraction of metallic core atoms to about $4 \%$ (Table 1 ). The coordination numbers that correspond to two Pd-Pd scatterings at 3.02 and $3.43 \AA$ decrease to 1.9 and 3.0, respectively. It should be stressed that the coordination number which corresponded to the $\mathrm{Pd}-\mathrm{O}_{\mathrm{Al}}$ scattering, on the contrary, increased to 1.0. These tendencies keep with the further increase in the temperature (Table 1). At $300{ }^{\circ} \mathrm{C}$, the coordination number corresponding to the $\mathrm{Pd}-\mathrm{Pd}$ scattering of the metal core decreases to 2.0 and the fraction of metallic core atoms drops to about $2 \%$, and at $400{ }^{\circ} \mathrm{C}$ there is no Pd-Pd scattering that could correspond to $\mathrm{Pd}$ atoms of the metallic core. This means that, above $300{ }^{\circ} \mathrm{C}$, the palladium is completely oxidized. The bulk oxidation of the $6 \mathrm{~nm}$ Pd nanoparticles in the oxidation of methane was previously observed by in situ XANES, but the temperature of the full oxidation of palladium was above $400{ }^{\circ} \mathrm{C}$ that is higher than in our case [39]. This could be due to the $\mathrm{Pd}^{0} / \mathrm{Pd}^{2+}$ equilibrium depending not only the reaction condition (temperature and partial pressure 
of oxygen), but also the particle size. The second important result concerns the change in the shape of the $\mathrm{Pd}$ nanoparticles. Indeed, the coordination number corresponding to the $\mathrm{Pd}-\mathrm{O}_{\mathrm{Al}}$ scattering increased to 1.2 at $400{ }^{\circ} \mathrm{C}$. On the other hand, the coordination numbers corresponding to two Pd-Pd scatterings decrease to 0.8 and 2.0, respectively. The observed trends show that the palladium nanoparticles undergo changes during the oxidation of methane. We consider that the increase in the coordination number corresponded to the $\mathrm{Pd}-\mathrm{O}_{\mathrm{Al}}$ scattering and a decrease in the coordination numbers corresponded to the $\mathrm{Pd}-\mathrm{Pd}$ scatterings are caused by the flattening of the palladium nanoparticles. The scheme of this change is presented in Figure 5. Flattening could be a result of the better wetting of the oxide support by the oxide nanoparticles. Such an effect was observed by an X-ray photoelectron spectroscopy (XPS) for Ni-based sol-gel catalysts when the reduction of the initially oxidized active component leads to the decrease in the [Metal]/[Support] surface ratio due to the increase in the size of the metal nanoparticle [1,2]. In our case, we observe the opposite effect, as the treatment in the oxidized atmosphere (the reaction mixture has an excess of oxygen) leads to an increase in the lateral size of oxide nanoparticles. This behavior of catalyst is reversible, as the decrease in the temperature leads to the reduction of the nanoparticle's core to the metallic state and to the increase in the coordination numbers corresponding to the Pd-Pd scatterings (Table 1, column after reaction (RT)). The nature of this effect will be clarified in the near future.

Table 1. Structural parameters: coordination number and the fraction of atoms in the metallic state obtained according to fits of $\mathrm{Pd} K$ - and $\mathrm{Pt} \mathrm{L}_{3}$-edges of $\mathrm{Pd} / \mathrm{Al}_{2} \mathrm{O}_{3}, \mathrm{Pt} / \mathrm{Al}_{2} \mathrm{O}_{3}$ and bimetallic $\mathrm{PdPt} / \mathrm{Al}_{2} \mathrm{O}_{3}$ catalysts.

\begin{tabular}{|c|c|c|c|c|c|c|}
\hline & & Fresh (RT) & $200{ }^{\circ} \mathrm{C}$ & $300^{\circ} \mathrm{C}$ & $400^{\circ} \mathrm{C}$ & After Reaction (RT) \\
\hline \multicolumn{7}{|c|}{$\mathrm{Pd} / \mathrm{Al}_{2} \mathrm{O}_{3}(\mathrm{Pd} K$-edge $)$} \\
\hline Fraction of metal & & $7 \%$ & $4 \%$ & $2 \%$ & $0 \%$ & $6 \%$ \\
\hline CN (Metal core) & $\mathrm{Pd}_{\text {met }}$ & 2.9 & 2.7 & 2.0 & - & 2.8 \\
\hline & $\mathrm{O}$ & 4.0 & 4.0 & 4.0 & 4.0 & 4.0 \\
\hline & $\mathrm{O}_{\mathrm{Al}}$ & 0.7 & 1.0 & 1.1 & 1.2 & 1.0 \\
\hline CNs (Oxide shell) & $\mathrm{Pd}$ & 2.6 & 1.9 & 0.9 & 0.8 & 3.1 \\
\hline & $\mathrm{Pd}$ & 3.3 & 3.0 & 2.0 & 2.0 & 3.6 \\
\hline \multicolumn{7}{|c|}{$\mathrm{Pt} / \mathrm{Al}_{2} \mathrm{O}_{3}\left(\mathrm{Pt} L_{3}\right.$-edge $)$} \\
\hline Fraction of metal & & $25 \%$ & $20 \%$ & $16 \%$ & $16 \%$ & $23 \%$ \\
\hline CN (Metal core) & $\mathrm{Pt}_{\text {met }}$ & 6.9 & 4.5 & 3.8 & 3.4 & 5.6 \\
\hline & $\mathrm{O}$ & 6.0 & 6.0 & 6.0 & 6.0 & 6.0 \\
\hline & $\mathrm{O}_{\mathrm{Al}}$ & 1.2 & 1.2 & 1.2 & 1.2 & 1.2 \\
\hline & $\mathrm{Al}$ & 0.6 & 0.6 & 0.6 & 0.6 & 0.6 \\
\hline CNs (Oxide shell) & $\mathrm{Pt}$ & 1.1 & 0.9 & 0.8 & 0.8 & 0.8 \\
\hline & $\mathrm{O}$ & 5.5 & 3.3 & 3.5 & 3.4 & 3.8 \\
\hline & $\mathrm{O}$ & 1.7 & 1.3 & 1.3 & 1.1 & 1.1 \\
\hline \multicolumn{7}{|c|}{$\mathrm{PdPt} / \mathrm{Al}_{2} \mathrm{O}_{3}$ (Pd K-edge) } \\
\hline Fraction of metal & & $9 \%$ & $12 \%$ & $10 \%$ & $10 \%$ & $10 \%$ \\
\hline CN (Metal core) & $\mathrm{Pd} / \mathrm{Pt}_{\mathrm{met}}$ & 1.5 & 0.9 & 1.0 & 0.9 & 0.8 \\
\hline & $\mathrm{O}$ & 4.0 & 4.0 & 4.0 & 4.0 & 4.0 \\
\hline & $\mathrm{O}_{\mathrm{Al}}$ & 1.3 & 1.0 & 1.1 & 1.1 & 1.0 \\
\hline CNs (Oxide shell) & $\mathrm{Al}$ & 0.2 & 0.2 & 0.2 & 0.2 & 0.2 \\
\hline & $\mathrm{Pd} / \mathrm{Pt}$ & 0.6 & 0.6 & 0.6 & 0.6 & 0.6 \\
\hline & $\mathrm{Pd} / \mathrm{Pt}$ & 1.0 & 0.9 & 1.0 & 0.9 & 0.9 \\
\hline \multicolumn{7}{|c|}{$\mathrm{PdPt} / \mathrm{Al}_{2} \mathrm{O}_{3}\left(\mathrm{Pt} L_{3}\right.$-edge $)$} \\
\hline Fraction of metal & & $25 \%$ & $26 \%$ & $24 \%$ & $25 \%$ & $27 \%$ \\
\hline CN (Metal core) & $\mathrm{Pt} / \mathrm{Pd}_{\mathrm{met}}$ & 4.0 & 3.6 & 3.4 & 2.8 & 3.6 \\
\hline \multirow{6}{*}{ CNs (Oxide shell) } & $\mathrm{O}$ & 6.0 & 6.0 & 6.0 & 6.0 & 6.0 \\
\hline & $\mathrm{O}_{\mathrm{Al}}$ & 1.2 & 1.5 & 1.2 & 1.2 & 1.5 \\
\hline & Al & 0.6 & 0.6 & 0.6 & 0.6 & 0.7 \\
\hline & $\mathrm{Pt} / \mathrm{Pd}$ & 1.6 & 0.8 & 0.9 & 0.8 & 0.8 \\
\hline & $\mathrm{O}$ & 5.8 & 3.3 & 3.5 & 3.5 & 3.1 \\
\hline & $\mathrm{O}$ & 1.0 & 1.3 & 1.1 & 1.1 & 2.8 \\
\hline
\end{tabular}


Evolution of $\mathrm{Pd}$ and $\mathrm{Pt}$ mono- and bimetallic catalysts during the $\mathrm{CH}_{4}$ oxidation
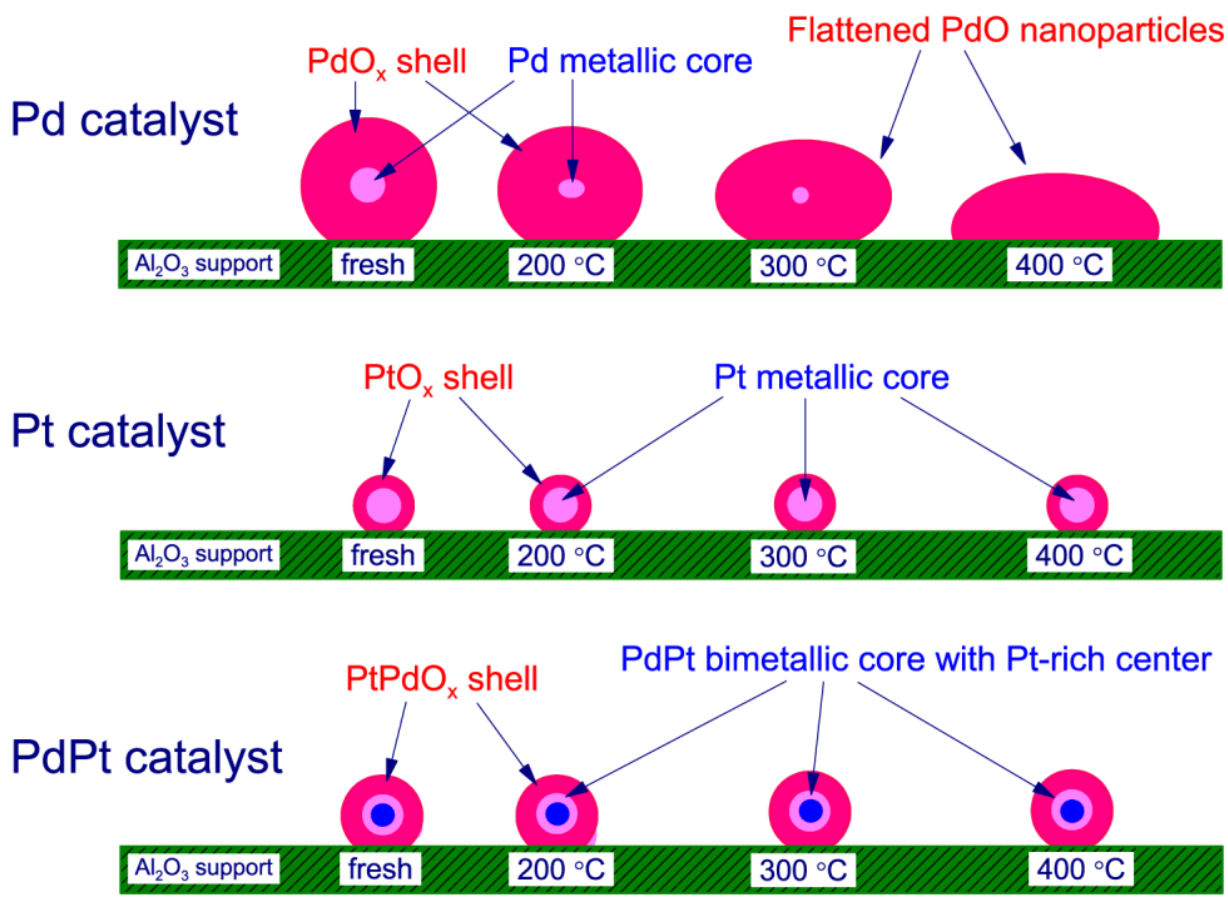

Figure 5. Proposed models of evolution of $\mathrm{Pd} / \mathrm{Al}_{2} \mathrm{O}_{3}, \mathrm{Pt} / \mathrm{Al}_{2} \mathrm{O}_{3}$ and bimetallic PdPt $/ \mathrm{Al}_{2} \mathrm{O}_{3}$ catalysts during the oxidation of methane.

The EXAFS Pt $L_{3}$-edge spectrum of the fresh $\mathrm{Pt} / \mathrm{Al}_{2} \mathrm{O}_{3}$ catalyst has an intense peak at approximately $1.63 \AA$ in the R- $\delta$ scale, which corresponds to the Pt-O scattering (Figure $4 \mathrm{~b}$, $\mathrm{RT})$. According to the fit, this peak corresponds to the 1st coordination sphere of the platinum oxide ( $2.01 \AA$ ). The region of $1.8-2.8 \AA$ in the $\mathrm{R}-\delta$ scale reveals the information about the $\mathrm{Pt}-\mathrm{O}_{\mathrm{Al}}$ and $\mathrm{Pt}-\mathrm{Al}$ scatterings of the oxide shell and the Pt-Pt scattering of the metallic core. According to the fit, the distance of $\mathrm{Pt}-\mathrm{O}_{\mathrm{Al}}$ is $2.35 \AA$ and the coordination number is 1.2. The distance of $\mathrm{Pt}-\mathrm{Al}$ is $2.85 \AA$ and the coordination number is 0.6 . The Pt-Pt distance for the metallic core is $2.79 \AA$ and the coordination number is 6.9. The area in the range of $2.8-3.7 \AA$ in the R- $\delta$ scale corresponds to the Pt-Pt scattering and two Pt-O scatterings of platinum oxides. According to the fit, the Pt-Pt distance is $3.20 \AA$ and the coordination number is 1.1. The Pt-O distances are $3.66 \AA$ and $3.84 \AA$ and the coordination numbers are 5.5 and 1.7, respectively. Moreover, in the case of $\mathrm{Pd} / \mathrm{Al}_{2} \mathrm{O}_{3}$ catalysts, the coordination numbers for all scatterings (except the Pt-O scattering for the oxide shell) are lower than ones for bulk $\mathrm{PtO}_{2}$ and metallic platinum, due to the extremely small size of nanoparticles (about $1.1 \mathrm{~nm}$ ). It should also be noted that the fraction of platinum atoms forming the metallic core is higher than in the case of the $\mathrm{Pd} / \mathrm{Al}_{2} \mathrm{O}_{3}$ catalyst and equals to $25 \%$.

The increase in the temperature leads to decreasing the coordination number corresponded to the Pt-Pt scattering of the metal core to $4.5,3.8$, and 3.4 at 200,300 , and $400{ }^{\circ} \mathrm{C}$, respectively. One can see that platinum in contrast to palladium does not completely oxidize under the reaction conditions. The fraction of metallic core atoms remains in the range of $16-20 \%$ (Table 1 ). The increase in the temperature does not lead to significant changes of the parameters corresponding to the outer oxide shell of platinum nanoparticles as well. Finally, cooling the reaction mixture to room temperature returns the catalyst closely to the initial state. All these facts indicate that the $\mathrm{Pt} / \mathrm{Al}_{2} \mathrm{O}_{3}$ catalyst is stable in the reaction conditions. The obtained result agrees well with the previous study of the Pt-based catalysts for the oxidation of $\mathrm{CO}$, it was shown that the more active and stable catalysts contain metallic platinum. The authors believed than the presence of a metal core leads to a 
metal-support interaction that stabilizes the Pt nanoparticles [40-43]. In our case, the TEM data and the results of in situ EXAFS spectroscopy prove the early proposed hypothesis.

Finally, we have used the same model to fit the $\mathrm{Pd} \mathrm{K}$ - and $\mathrm{Pt} L_{3}$-edge spectra of the bimetallic $\mathrm{PdPt} / \mathrm{Al}_{2} \mathrm{O}_{3}$ catalyst considering that the active component is the alloyed PdPt nanoparticles. The results of fitting are presented in Figure $4 b, c$ and summarized in Table 1. One can see that significant differences are observed at the $\mathrm{Pd} K$-edge spectra. The intensity of a wide peak in the range of 2.6-3.5 $\AA$ in the R- $\delta$ scale corresponded to two Pd-Pd scattering of palladium oxide is lower than in the case of the $\mathrm{Pd} / \mathrm{Al}_{2} \mathrm{O}_{3}$ catalyst (Figure 4a). This means that the outer oxide shell is thinner than in the case of the $\mathrm{Pd} / \mathrm{Al}_{2} \mathrm{O}_{3}$ catalyst. The second difference is that the fraction of atoms forming the metal core is higher than in the case of the $\mathrm{Pd} / \mathrm{Al}_{2} \mathrm{O}_{3}$ catalyst and palladium in the metal state is observed even at $400{ }^{\circ} \mathrm{C}$. At the same time, the coordination number is lower than in case of the $\mathrm{Pd} / \mathrm{Al}_{2} \mathrm{O}_{3}$ catalyst, which could be due to the core-shell structure of nanoparticles. Indeed, according to the fit of $\mathrm{Pt} L_{3}$-edges, the coordination number and the fraction of platinum atoms forming the metal core is close to that of the $\mathrm{Pt} / \mathrm{Al}_{2} \mathrm{O}_{3}$ catalyst. Both facts allow us to speculate that the metal core is formed by Pd-Pt alloy with the Pt-rich center (Figure 5). The structure of the oxide shell is stable with heating (the slight decrease in the coordination numbers for both edges are observed). A more significant result could be figured out taking into account that the $\mathrm{PdPt} / \mathrm{Al}_{2} \mathrm{O}_{3}$ catalyst has the Pd:Pt molar ratio closed to 1:1. Thus, the fraction of palladium and platinum atoms forming the oxide shell is about $90 \%$ and $75 \%$, respectively. This means that the shell is Pd-rich while the core is Pt-rich. It should be stressed that such a structure of the bimetallic PdPt nanoparticles was proposed by several research groups, and it was considered that the presence of metallic core preserves the active component against the redox transformation [34,35,44]. Thus, the carried out in situ EXAFS study unambiguously proves that hypothesis. Moreover, the proposed model disputes that the participation in the catalytic process of both palladium oxide and metallic palladium is essential, on the basis of the XPS study [14,24]. Indeed, when studying the core-shell structures by XPS, both $\mathrm{Pd}^{0}$ and $\mathrm{Pd}^{2+}$ could be detected, while the oxidation of methane occurs only on the surface of the oxide shell of the nanoparticles.

\section{Materials and Methods}

\subsection{Catalyst Synthesis}

The mono- and bimetallic $\mathrm{Pd}$ and Pt catalysts were prepared by the incipient wetness impregnation of $\gamma$-alumina $\left(\mathrm{S}_{\mathrm{BET}}=150 \mathrm{~m}^{2} / \mathrm{g}\right.$, Puralox HP-14/150, Sasol, Sandton, South Africa) by solution of palladium and/or platinum nitrates with glycine. Before the impregnation, the alumina was treated by $20 \%$ acetic acid to increase the uniform distribution of metal nanoparticles over surface due to the competitive sorption. The molar ratio of metal $/ \mathrm{NO}_{3}$ in the impregnating solution was $1 / 8$, additionally the glycine was added to the solution (molar ration of metal/glycine $=2$ ). In the case of noble metals, the addition of glycine leads to the formation of $\mathrm{Pt}(\mathrm{Pd})$-glycine complexes of unknown structure, which makes it possible to additionally disperse the noble metal over the support surface [45]. Heat treatment of an air-dry sample in an oxidizing atmosphere initiates the combustion of glycine and the rapid self-propagating flameless combustion of a mixture of glycine-Pt( $\mathrm{Pd})$ nitrate, leading to the formation of highly dispersed particles [46]. The heat treatment of the catalysts was performed at $450{ }^{\circ} \mathrm{C}$ in an air flow. Three catalysts were synthesized: $3 \mathrm{wt} \% \mathrm{Pd} / \mathrm{Al}_{2} \mathrm{O}_{3}, 3 \mathrm{wt} \% \mathrm{Pt} / \mathrm{Al}_{2} \mathrm{O}_{3}$, and $(1 \mathrm{wt} \% \mathrm{Pd}+2 \mathrm{wt} \% \mathrm{Pt}) / \mathrm{Al}_{2} \mathrm{O}_{3}$.

\subsection{Catalytic Activity Tests}

The catalysts were tested in the oxidation of methane in a temperature range of $100-500{ }^{\circ} \mathrm{C}$ at a gas hourly space velocity (GHSV) of $2000 \mathrm{~h}^{-1}$ using a catalytic setup with a flow fixed bed reactor. The volume of the testing catalyst was $0.5 \mathrm{~cm}^{3}$. To avoid the local overheating of the catalyst and to reduce the gas-phase oxidation of methane, a catalyst fraction with a grain size of $0.5-1.0 \mathrm{~mm}$ was mixed with quartz in the ratio of $1: 1$. The reaction feed contained $1 \mathrm{vol} . \%$ of methane, 4 vol.\% of oxygen, and nitrogen. The reagents 
and reaction products were analyzed on a Tcwet-500 gas chromatograph (Tcwet LLC., Yoshkar-Ola, Russia) equipped with a thermal conductivity detector. A Porapak Q column (inside diameter, $3 \mathrm{~mm}$; length, $3 \mathrm{~m}$ ) was used for the separation of methane, $\mathrm{CO}_{2}$, and water, and a column packed with molecular sieves $\mathrm{NaX}$ (inside diameter, $3 \mathrm{~mm}$; length, $2 \mathrm{~m}$ ) was used for the determination of oxygen. The catalytic activity was estimated by light-off temperature.

\subsection{High Resolution Transmission Electron Microscopy}

The morphology and the size distribution of catalysts were investigated by Themis Z electron microscope (Thermo Fisher Scientific, Waltham, MA, USA) equipped with a corrector of spherical aberrations, which provided a maximum lattice resolution of $0.06 \mathrm{~nm}$ at the accelerating voltage of $200 \mathrm{kV}$. Images were recorded using Ceta 16 CCD sensor (Thermo Fisher Scientific, Waltham, MA, USA). Additionally, in a case of the bimetallic catalyst, the surface distribution of $\mathrm{Pd}$ and $\mathrm{Pt}$ atoms was studied by energy dispersive X-Ray (EDX) spectroscopy (EDX Super-X detector, Thermo Fisher Scientific, Waltham, MA, USA). The samples for the HRTEM study were prepared on a holey carbon film mounted on a copper grid by the ultrasonic dispersing of the catalyst suspension in ethanol.

\subsection{X-ray Absorption Spectroscopy}

The X-ray absorption spectroscopy study was performed at the Structural Materials Science beamline at the Kurchatov Synchrotron Radiation Source (National Research Center "Kurchatov Institute", Moscow, Russia). The experimental station is described in detail elsewhere [47]. The spectra were obtained at the $\mathrm{Pt} L_{3}$-edge in the transmission mode using a channel-cut $\mathrm{Si}(111)$ monochromator and at the Pd K-edge in the transmission mode using a channel-cut $\mathrm{Si}(311)$ monochromator. Powder samples were pressed into thin self-supporting pellets, mounted to a stainless steel sample-holder and then placed in a custom-made reaction chamber for in situ EXAFS measurements [48]. To obtain an appropriate $X$-ray absorption, the samples were diluted by a fine powder of hexagonal $\mathrm{BN}$. The local structure of the $\mathrm{Pd}$ and $\mathrm{Pt}$ atoms was studied in the flow of reaction mixture at atmospheric pressure at room temperature, 200, 300, and $400{ }^{\circ} \mathrm{C}$. The reaction mixture consisted of 1 vol. $\% \mathrm{CH}_{4}, 4$ vol. $\% \mathrm{O}_{2}$, and $\mathrm{He}$ (rest), the gas flows were controlled by SEC-Z500X flow mass controllers (Horiba Ltd., Kyoto, Japan). Two ionization chambers, filled with appropriate $\mathrm{N}_{2}$-Ar mixtures were used as detectors. The ionization currents were measured by Keithley 6487 digital picoamperemeters (Keithley Instruments LLC, Cleveland, $\mathrm{OH}, \mathrm{USA})$. Energy calibration was performed using the first inflection point in the $\mathrm{Pt} \mathrm{L}_{3}$-edge spectra of Pt foil at 11,564 eV and in the Pd K-edge spectra of Pd foil at $24,350 \mathrm{eV}$. The spectra were processed using standard procedures for subtracting the background and normalizing to the magnitude of the $L_{3}$ - and $K$-absorption edge jump using the DEMETER software package [49]. The radial pair distribution functions around the $\mathrm{Pt}$ and Pd atoms were obtained by the Fourier transform of the $k^{2}$-weighted EXAFS functions over the range of photoelectron wave numbers 1.2-12.5 $\AA^{-1}$. For a correct interpretation of the EXAFS data, a simulation of the spectra was performed based on a preliminary model constructed using crystallographic data [50]. After that, the theoretical curve of EXAFS oscillations, which is the sum of single and multiple scattering paths considering several coordination spheres, was calculated. The minimization of the function of discrepancy between the theoretical and experimental spectra using the FEFF6 software [51] made it possible to refine the parameters of the used model and determine the coordination numbers, radii of coordination spheres, and Debye-Waller factors.

\section{Conclusions}

The oxidation of methane over supported $3 \% \mathrm{Pd} / \mathrm{Al}_{2} \mathrm{O}_{3}, 3 \% \mathrm{Pt} / \mathrm{Al}_{2} \mathrm{O}_{3}$ and bimetallic $(1 \% \mathrm{Pd}+2 \% \mathrm{Pt}) / \mathrm{Al}_{2} \mathrm{O}_{3}$ catalysts has been studied in a flow fixed bed reactor in the temperature range of $150-400{ }^{\circ} \mathrm{C}$. High resolution TEM analysis has shown that the used synthesis allows to prepare the Pd-, Pt-, and PdPt-based catalysts with narrow particle size 
distribution and mean size of 2.7, 1.1, and $1.3 \mathrm{~nm}$, respectively. Based on the TEM and EXAFS spectroscopy study, it was shown that for all the catalysts the active component exists in the "core-shell" structure with the metal core covered by the oxide shell. The in-situ EXAFS study allowed us to clarify the evolution of the active component with temperature under the reaction conditions.

Supplementary Materials: The following are available online at https:/ /www.mdpi.com/article/ 10.3390/catal11121446/s1, Figure S1: EDX mapping (in HAADF STEM mode) of the bimetallic $\mathrm{PdPt} / \mathrm{Al}_{2} \mathrm{O}_{3}$ catalyst after reaction, Table S1: Structural parameters: coordination number, interatomic distance $\mathrm{R}(\AA)$, and Debye-Waller factor $\sigma^{2}\left(\AA^{2}\right)$, obtained from the refinement of experimental EXAFS data for the catalyst under study, as well as the energy shift $\Delta \mathrm{E}_{0}$, and $R$-factor.

Author Contributions: Conceptualization, A.A.S., S.A.Y. and V.V.K.; methodology, A.A.S.; validation, A.A.S., S.A.Y. and V.V.K.; formal analysis, A.A.S. and A.M.K.; investigation, A.A.S., S.A.Y., E.Y.G. and Z.S.V.; writing—original draft preparation, A.A.S.; writing—review and editing, A.A.S., S.A.Y. and V.V.K.; visualization, A.A.S.; supervision, V.V.K.; project administration, A.A.S.; funding acquisition, A.A.S. All authors have read and agreed to the published version of the manuscript.

Funding: The reported study was funded by RFBR (project number 20-33-70124) and within the framework of budget project for Synchrotron radiation facility SKIF, Boreskov Institute of Catalysis.

Data Availability Statement: Data is contained within the article and Supplementary Materials.

Acknowledgments: The TEM study was carried out using facilities of the shared research center "National center of investigation of catalysts" at Boreskov Institute of Catalysis. The authors thank Eugenie Khramov, Alexander Trigub, and Alexey Veligzhanin for their support during the beamtime at the Kurchatov Synchrotron Radiation Source (Kurchatov Institute, Moscow, Russia).

Conflicts of Interest: The authors declare no conflict of interest.

\section{References}

1. Bykova, M.V.; Ermakov, D.Y.; Kaichev, V.V.; Bulavchenko, O.A.; Saraev, A.A.; Lebedev, M.Y.; Yakovlev, V.A. Ni-based sol-gel catalysts as promising systems for crude bio-oil upgrading: Guaiacol hydrodeoxygenation study. Appl. Catal. B 2012, 113-114, 296-307. [CrossRef]

2. Khromova, S.A.; Bykova, M.V.; Bulavchenko, O.A.; Ermakov, D.Y.; Saraev, A.A.; Kaichev, V.V.; Venderbosch, R.H.; Yakovlev, V.A. Furfural hydrogenation to furfuryl alcohol over bimetallic Ni-Cu sol-gel catalyst: A model reaction for conversion of oxygenates in pyrolysis liquids. Top. Catal. 2016, 59, 1413-1423. [CrossRef]

3. Panafidin, M.A.; Bukhtiyarov, A.V.; Prosvirin, I.P.; Chetyrin, I.A.; Bukhtiyarov, V.I. Model bimetallic Pd-Ag/HOPG catalysts: An XPS and STM study. Kinet. Catal. 2019, 59, 776-785. [CrossRef]

4. Fedorov, A.; Saraev, A.; Kremneva, A.; Selivanova, A.; Vorokhta, M.; Šmíd, B.; Bulavchenko, O.; Yakovlev, V.; Kaichev, V. Kinetic and mechanistic study of $\mathrm{CO}$ oxidation over nanocomposite $\mathrm{Cu}-\mathrm{Fe}-\mathrm{Al}$ oxide catalysts. ChemCatChem 2020, 12, $4911-4921$. [CrossRef]

5. Ulrich, V.; Moroz, B.; Pyrjaev, P.; Sinev, I.; Bukhtiyarov, A.; Gerasimov, E.; Bukhtiyarov, V.; Cuenya, B.R.; Grünert, W. Three-way catalysis with bimetallic supported Pd-Au catalysts: Gold as a poison and as a promotor. Appl. Catal. B 2021, $282,119614$. [CrossRef]

6. Gulyaeva, Y.; Alekseeva, M.V.; Bulavchenko, O.; Kremneva, A.; Saraev, A.; Gerasimov, E.; Selishcheva, S.; Kaichev, V.; Yakovlev, V. $\mathrm{Ni}-\mathrm{Cu}$ high-loaded sol-gel catalysts for dehydrogenation of liquid organic hydrides: Insights into structural features and relationship with catalytic activity. Nanomaterials 2021, 11, 2017. [CrossRef]

7. Smirnova, N.S.; Khramov, E.V.; Baeva, G.N.; Markov, P.V.; Bukhtiyarov, A.V.; Zubavichus, Y.V.; Stakheev, A.Y. An investigation into the bulk and surface phase transformations of bimetallic $\mathrm{Pd}-\mathrm{In} / \mathrm{Al}_{2} \mathrm{O}_{3}$ catalyst during reductive and oxidative treatments $\mathrm{In}$ situ. Catalysts 2021, 11, 859. [CrossRef]

8. Ahmadi, M.; Mistry, H.; Roldan Cuenya, B. Tailoring the catalytic properties of metal nanoparticles via support interactions. J. Phys. Chem. Lett. 2016, 7, 3519-3533. [CrossRef]

9. Liu, L.; Corma, A. Metal catalysts for heterogeneous catalysis: From single atoms to nanoclusters and nanoparticles. Chem. Rev. 2018, 118, 4981-5079. [CrossRef]

10. Piccolo, L. Restructuring effects of the chemical environment in metal nanocatalysis and single-atom catalysis. Catal. Today 2021, 373, 80-97. [CrossRef]

11. Shelef, M.; McCabe, R.W. Twenty-five years after introduction of automotive catalysts: What next? Catal. Today 2000, 62, 35-50. [CrossRef]

12. Haaß, F.; Fuess, H. Structural characterization of automotive catalysts. Adv. Eng. Mater. 2005, 7, 899-913. [CrossRef] 
13. Wang, Y.; Xu, H.; Shang, H.; Gong, M.; Chen, Y. Excellent complete conversion activity for methane and $\mathrm{CO}$ of $\mathrm{Pd} / \mathrm{TiO}_{2}-$ $\mathrm{Zr}_{0.5} \mathrm{Al}_{0.5} \mathrm{O}_{1.75}$ catalyst used in lean-burn natural gas vehicles. J. Energy Chem. 2014, 23, 461-467. [CrossRef]

14. Huang, F.; Chen, J.; Hu, W.; Li, G.; Wu, Y.; Yuan, S.; Zhong, L.; Chen, Y. Pd or PdO: Catalytic active site of methane oxidation operated close to stoichiometric air-to-fuel for natural gas vehicles. Appl. Catal. B 2017, 219, 73-81. [CrossRef]

15. Liu, X.; Chen, J.; Zhang, G.; Wu, Y.; Shen, P.; Zhong, L.; Chen, Y. Tuning the interactions among Ce, Pd and Rh over Ce-modified Pd-Rh three-way catalyst for exhaust treatment of natural gas vehicles. J. Environ. Chem. Eng. 2021, 9, 105570. [CrossRef]

16. Willis, J.J.; Gallo, A.; Sokaras, D.; Aljama, H.; Nowak, S.H.; Goodman, E.D.; Wu, L.; Tassone, C.J.; Jaramillo, T.F.; Abild-Pedersen, F.; et al. Systematic structure-property relationship studies in Palladium-catalyzed methane complete combustion. ACS Catal. 2017, 7, 7810-7821. [CrossRef]

17. Nilsson, J.; Carlsson, P.-A.; Martin, N.M.; Adams, E.C.; Agostini, G.; Grönbeck, H.; Skoglundh, M. Methane oxidation over $\mathrm{Pd} / \mathrm{Al}_{2} \mathrm{O}_{3}$ under rich/lean cycling followed by operando XAFS and modulation excitation spectroscopy. J. Catal. 2017, 356, 237-245. [CrossRef]

18. Chen, J.; Zhong, J.; Wu, Y.; Hu, W.; Qu, P.; Xiao, X.; Zhang, G.; Liu, X.; Jiao, Y.; Zhong, L.; et al. Particle size effects in stoichiometric methane combustion: Structure-activity relationship of Pd catalyst supported on gamma-Alumina. ACS Catal. 2020, 10, 10339-10349. [CrossRef]

19. Bychkov, V.Y.; Tyulenin, Y.P.; Gorenberg, A.Y.; Sokolov, S.; Korchak, V.N. Evolution of Pd catalyst structure and activity during catalytic oxidation of methane and ethane. Appl. Catal. A 2014, 485, 1-9. [CrossRef]

20. Sadokhina, N.; Ghasempour, F.; Auvray, X.; Smedler, G.; Nylén, U.; Olofsson, M.; Olsson, L. An experimental and kinetic modelling study for methane oxidation over Pd-based catalyst: Inhibition by water. Catal. Lett. 2017, 147, 2360-2371. [CrossRef]

21. Baylet, A.; Marecot, P.; Duprez, D.; Castellazzi, P.; Groppi, G.; Forzatti, P. In situ Raman and in situ XRD analysis of PdO reduction and $\mathrm{Pd}$ degrees oxidation supported on gamma- $\mathrm{Al}_{2} \mathrm{O}_{3}$ catalyst under different atmospheres. Phys. Chem. Chem. Phys. 2011, 13, 4607-4613. [CrossRef]

22. Murata, K.; Kosuge, D.; Ohyama, J.; Mahara, Y.; Yamamoto, Y.; Arai, S.; Satsuma, A. Exploiting metal-support interactions to tune the redox properties of supported Pd catalysts for methane combustion. ACS Catal. 2019, 10, 1381-1387. [CrossRef]

23. Zhu, G.; Han, J.; Zemlyanov, D.Y.; Ribeiro, F.H. The turnover rate for the catalytic combustion of methane over palladium is not sensitive to the structure of the catalyst. J. Am. Chem. Soc. 2004, 126, 9896-9897. [CrossRef]

24. Stakheev, A.Y.; Batkin, A.M.; Teleguina, N.S.; Bragina, G.O.; Zaikovsky, V.I.; Prosvirin, I.P.; Khudorozhkov, A.K.; Bukhtiyarov, V.I. Particle size effect on $\mathrm{CH}_{4}$ oxidation over noble metals: Comparison of Pt and Pd catalysts. Top. Catal. 2013, 56, 306-310. [CrossRef]

25. Murata, K.; Ohyama, J.; Yamamoto, Y.; Arai, S.; Satsuma, A. Methane combustion over $\mathrm{Pd} / \mathrm{Al}_{2} \mathrm{O}_{3}$ catalysts in the presence of water: Effects of Pd particle size and alumina crystalline phase. ACS Catal. 2020, 10, 8149-8156. [CrossRef]

26. Hutchings, G.J. Nanocrystalline gold and gold-palladium alloy oxidation catalysts: A personal reflection on the nature of the active sites. Dalton Trans. 2008, 5523-5536. [CrossRef]

27. Shan, S.; Petkov, V.; Yang, L.; Luo, J.; Joseph, P.; Mayzel, D.; Prasai, B.; Wang, L.; Engelhard, M.; Zhong, C.J. Atomic-structural synergy for catalytic CO oxidation over palladium-nickel nanoalloys. J. Am. Chem. Soc. 2014, 136, 7140-7151. [CrossRef]

28. Yashnik, S.A.; Denisov, S.P.; Danchenko, N.M.; Ismagilov, Z.R. Synergetic effect of Pd addition on catalytic behavior of monolithic platinum-manganese-alumina catalysts for diesel vehicle emission control. Appl. Catal. B 2016, 185, 322-336. [CrossRef]

29. Yashnik, S.A.; Chesalov, Y.A.; Ishchenko, A.V.; Kaichev, V.V.; Ismagilov, Z.R. Effect of Pt addition on sulfur dioxide and water vapor tolerance of Pd-Mn-hexaaluminate catalysts for high-temperature oxidation of methane. Appl. Catal. B 2017, 204, 89-106. [CrossRef]

30. Nguyen, T.S.; McKeever, P.; Arredondo-Arechavala, M.; Wang, Y.-C.; Slater, T.J.A.; Haigh, S.J.; Beale, A.M.; Thompson, J.M. Correlation of the ratio of metallic to oxide species with activity of PdPt catalysts for methane oxidation. Catal. Sci. Technol. 2020, 10, 1408-1421. [CrossRef]

31. Lee, J.; Kim, M.Y.; Jeon, J.H.; Lee, D.H.; Rao, K.N.; Oh, D.G.; Jang, E.J.; Kim, E.; Na, S.C.; Han, H.S.; et al. Effect of Pt pre-sintering on the durability of $\mathrm{PtPd} / \mathrm{Al}_{2} \mathrm{O}_{3}$ catalysts for $\mathrm{CH}_{4}$ oxidation. Appl. Catal. B 2020, 260, 118098. [CrossRef]

32. Xiong, H.; Kunwar, D.; Jiang, D.; García-Vargas, C.E.; Li, H.; Du, C.; Canning, G.; Pereira-Hernandez, X.I.; Wan, Q.; Lin, S.; et al. Engineering catalyst supports to stabilize $\mathrm{PdO}_{\mathrm{x}}$ two-dimensional rafts for water-tolerant methane oxidation. Nat. Catal. 2021, 4, 830-839. [CrossRef]

33. Mussio, A.; Danielis, M.; Divins, N.J.; Llorca, J.; Colussi, S.; Trovarelli, A. Structural evolution of bimetallic PtPd/CeO 2 methane oxidation catalysts prepared by dry milling. ACS Appl. Mater. Interfaces 2021, 13, 31614-31623. [CrossRef]

34. Carrillo, C.; Johns, T.R.; Xiong, H.; DeLaRiva, A.; Challa, S.R.; Goeke, R.S.; Artyushkova, K.; Li, W.; Kim, C.H.; Datye, A.K. Trapping of mobile Pt species by PdO nanoparticles under oxidizing conditions. J. Phys. Chem. Lett. 2014, 5, 2089-2093. [CrossRef]

35. Johns, T.R.; Goeke, R.S.; Ashbacher, V.; Thüne, P.C.; Niemantsverdriet, J.W.; Kiefer, B.; Kim, C.H.; Balogh, M.P.; Datye, A.K. Relating adatom emission to improved durability of Pt-Pd diesel oxidation catalysts. J. Catal. 2015, 328, 151-164. [CrossRef]

36. Bukhtiyarov, A.V.; Prosvirin, I.P.; Saraev, A.A.; Klyushin, A.Y.; Knop-Gericke, A.; Bukhtiyarov, V.I. In situ formation of the active sites in Pd-Au bimetallic nanocatalysts for CO oxidation: NAP (near ambient pressure) XPS and MS study. Faraday Discuss. 2018, 208, 255-268. [CrossRef]

37. Panafidin, M.A.; Bukhtiyarov, A.V.; Klyushin, A.Y.; Prosvirin, I.P.; Chetyrin, I.A.; Bukhtiyarov, V.I. Pd-Cu/HOPG and PdAg/HOPG model catalysts in CO and methanol oxidations at submillibar pressures. Kinet. Catal. 2020, 60, 832-841. [CrossRef] 
38. Glyzdova, D.V.; Afonasenko, T.N.; Khramov, E.V.; Leont'eva, N.N.; Prosvirin, I.P.; Bukhtiyarov, A.V.; Shlyapin, D.A. Liquid-phase acetylene hydrogenation over Ag-modified Pd/Sibunit catalysts: Effect of Pd to Ag molar ratio. Appl. Catal. A 2020, 600, 117627. [CrossRef]

39. Nilsson, J.; Carlsson, P.-A.; Martin, N.M.; Velin, P.; Meira, D.M.; Grönbeck, H.; Skoglundh, M. Oxygen step-response experiments for methane oxidation over Pd/ $\mathrm{Al}_{2} \mathrm{O}_{3}$ : An in situ XAFS study. Catal. Commun. 2018, 109, 24-27. [CrossRef]

40. Singh, J.; Alayon, E.M.; Tromp, M.; Safonova, O.V.; Glatzel, P.; Nachtegaal, M.; Frahm, R.; van Bokhoven, J.A. Generating highly active partially oxidized platinum during oxidation of carbon monoxide over $\mathrm{Pt} / \mathrm{Al}_{2} \mathrm{O}_{3}$ : In situ, time-resolved, and high-energy-resolution X-ray absorption spectroscopy. Angew. Chem. 2008, 47, 9260-9264. [CrossRef]

41. Alayon, E.M.C.; Singh, J.; Nachtegaal, M.; Harfouche, M.; van Bokhoven, J.A. In situ XAS probes partially oxidized platinum generating high activity for CO oxidation. J. Phys. Conf. Ser. 2009, 190, 012152. [CrossRef]

42. Marchionni, V.; Kambolis, A.; Nachtegaal, M.; Kröcher, O.; Ferri, D. High energy X-ray diffraction and IR spectroscopy of $\mathrm{Pt} / \mathrm{Al}_{2} \mathrm{O}_{3}$ during $\mathrm{CO}$ oxidation in a novel catalytic reactor cell. Catal. Struct. React. 2017, 3, 71-78. [CrossRef]

43. Lee, J.; Jang, E.J.; Oh, D.G.; Szanyi, J.; Kwak, J.H. Morphology and size of Pt on $\mathrm{Al}_{2} \mathrm{O}_{3}$ : The role of specific metal-support interactions between $\mathrm{Pt}$ and $\mathrm{Al}_{2} \mathrm{O}_{3}$. J. Catal. 2020, 385, 204-212. [CrossRef]

44. Martin, N.M.; Nilsson, J.; Skoglundh, M.; Adams, E.C.; Wang, X.; Smedler, G.; Raj, A.; Thompsett, D.; Agostini, G.; Carlson, S.; et al. Study of methane oxidation over alumina supported Pd-Pt catalysts using operando DRIFTS/MS and in situ XAS techniques. Catal. Struct. React. 2017, 3, 24-32. [CrossRef]

45. Shikina, N.V.; Yashnik, S.A.; Gavrilova, A.A.; Nikolaeva, O.A.; Dovlitova, L.S.; Ishchenko, A.V.; Ismagilov, Z.R. Effect of the conditions of solution combustion synthesis on the properties of monolithic $\mathrm{Pt}-\mathrm{MnO}_{\mathrm{x}}$ catalysts for deep oxidation of hydrocarbons. Kinet. Catal. 2020, 61, 809-823. [CrossRef]

46. Shikina, N.V.; Yashnik, S.A.; Gavrilova, A.A.; Ishchenko, A.V.; Dovlitova, L.S.; Khairulin, S.R.; Ismagilov, Z.R. Effect of glycine addition on physicochemical and catalytic properties of Mn, Mn-La and Mn-Ce monolithic catalysts prepared by solution combustion synthesis. Catal. Lett. 2019, 149, 2535-2551. [CrossRef]

47. Chernyshov, A.A.; Veligzhanin, A.A.; Zubavichus, Y.V. Structural materials science end-station at the kurchatov synchrotron radiation source: Recent instrumentation upgrades and experimental results. Nucl. Instrum. Methods Phys. Res. Sect. A 2009, 603, 95-98. [CrossRef]

48. Veligzhanin, A.A.; Zubavichus, Y.V.; Chernyshov, A.A.; Trigub, A.L.; Khlebnikov, A.S.; Nizovskii, A.I.; Khudorozhkov, A.K.; Beck, I.É; Bukhtiyarov, V.I. An in situ cell for investigation of the catalyst structure using synchrotron radiation. J. Struct. Chem. 2011, 51, 20-27. [CrossRef]

49. Ravel, B.; Newville, M. ATHENA, ARTEMIS, HEPHAESTUS: Data analysis for X-ray absorption spectroscopy using IFEFFIT. J. Synchrotron Radiat. 2005, 12, 537-541. [CrossRef]

50. ISCD (Inorganic Crystal Structure Database). Available online: https:/ /icsd.products.fiz-karlsruhe.de/ (accessed on 1 September 2021).

51. Rehr, J.J.; Mustre de Leon, J.; Zabinsky, S.I.; Albers, R.C. Theoretical X-ray absorption fine structure standards. J. Am. Chem. Soc. 1991, 113, 5135-5140. [CrossRef] 